\section{The path of canine visceral leishmaniasis versus the path of Center for Zoonoses Control: contributions of spatial analysis to health}

\section{O caminho da leishmaniose visceral canina versus o caminho do Centro de Controle de Zoonoses: contribuições da análise espacial para a saúde}

\section{La trayectoria de la leishmaniasis visceral canina versus la trayectoria del Centro para el Control de Zoonoses: contribuciones del análisis espacial a la salud}

\author{
Patricia Sayuri Silvestre Matsumoto 1,2 \\ Edilson Ferreira Flores 2 \\ José Seguinot Barbosa 3 \\ Umberto Catarino Pessoto 4 \\ José Eduardo Tolezano 1 \\ Roberto Mitsuyoshi Hiramoto 1 \\ Helena Hilomi Taniguchi 1 \\ Raul Borges Guimarães 2
}

doi: 10.1590/0102-311X00272020

\begin{abstract}
Visceral leishmaniasis (VL) is a public health problem in Brazilian municipalities. As much as there is a planning of public policies regards VL in São Paulo State, new cases have been reported and spread. This paper aims to discuss how the Center for Zoonoses Control conducts its actions spatially in endemic city of Presidente Prudente, São Paulo State. Data are from the Municipal Health Department of Presidente Prudente, Adolfo Lutz Institute, and Brazilian Institute of Geography and Statistics. We spatially estimated the dog population per census tract and used geoprocessing tools to perform choropleth maps, spatial trends, and spatial autocorrelation. We found a spatial pattern of higher prevalence in the city's outskirt and a positive statistically significant spatial autocorrelation $(I=0.2$, p-value $<0.000)$ with clusters of highhigh relationships in the Northwest part of the city. Moreover, we identified a different direction in the path of the conducted serosurveys versus the canine $V L$ trend, which stresses the fragility of the Center for Zoonoses Control actions to control the disease. The Center for Zoonoses Control always seems to chase the disease. The spatial analysis may be useful for rethinking how the service works and helps in public policies.
\end{abstract}

Visceral Leishmaniasis; Decision-Making; Epidemiologic Surveillances

\author{
Correspondence \\ P. S. S. Matsumoto \\ Instituto Adolfo Lutz. \\ Av. Dr. Arnaldo 355, São Paulo, SP 01246-000, Brazil. \\ patricia@matsumoto.geo.br \\ 1 Instituto Adolfo Lutz, São Paulo, Brasil. \\ 2 Faculdade de Ciências e Tecnologia, Universidade Estadual \\ Paulista Júlio de Mesquita Filho, Presidente Prudente, Brasil. \\ 3 Universidad de Puerto Rico, San Juan, Puerto Rico. \\ 4 Superintendência de Controle de Endemias, Secretaria de \\ Estado da Saúde de São Paulo, São Paulo, Brasil.
}




\section{Introduction}

Visceral leishmaniasis (VL) is a vector-borne disease that affects people and animals worldwide 1 . This disease is caused by protozoans of the Leishmania genus, transmitted by sandflies via bitting during blood feeding. Many species are found in the Leishmania group, but in Brazil, L. (L.) infantum chagasi has been diagnosed, and the main vector is Lutzomyia longipalpis species 2,3,4.

VL is endemic in 98 countries and territories. The World Health Organization (WHO) reported 17,000 cases of this disease in 2018, out of which almost 90\% of them occurred in India, Brazil, Sudan, South Sudan, Ethiopia, and Kenya. Brazil presented the second highest frequency of cases, totalizing 3,460 cases 1 . In the Americas, VL is endemic in 12 countries, where 63,331 new cases were reported from 2001 to 2018, and 61,048 (96.4\%) occurred in Brazil 5 .

Currently, all regions of Brazil registered autochthones cases, except in the states of Acre, Amazonas, and Rondônia, in the North Region 6. In the State of São Paulo, the first confirmed autochthonous canine and human case occurred in 1998 and 1999, respectively, in Araçatuba, Northwest Region of the State 7. In West São Paulo, Presidente Prudente is a central municipality to the region and discovered autochthonous canine cases in early 2010. No human cases were reported until 2013 8,9. Nowadays, the disease affects dogs and people, being a public health problem.

In Brazil, the domestic dog is the main reservoir. Most of them are euthanized when positive in serology diagnoses as a recommendation of the Brazilian Visceral Leishmaniasis Surveillance and Control Program (VLSCP)/Brazilian Ministry of Health 4 . The canine treatment became possible via regulation at the end of 201610,11 . However, this treatment is expensive, and its high-efficacy is still unproven. In humans, if VL is not diagnosed and treated, it can lead to death 1.

VLSCP suggests that municipalities should follow its guidelines to prevent and to control the disease. Nonetheless, different measures against VL can be found, depending on the actions taken at the local level, represented by the vector control, epidemiological surveillance, and Center for Zoonoses Control. In Presidente Prudente, the last performs serosurveys regularly. Thus, this paper aims twofold: (i) to analyze spatial patterns of canine visceral leishmaniasis (CVL) in an endemic city of the State of São Paulo, and (ii) to analyze how the Center for Zoonoses Control conducts its actions spatially in the city. We used geoprocessing tools to estimate the canine population and to identify the disease cases and serosurveys paths. We also applied statistical functions to find disease clusters.

Many papers have discussed leishmaniasis via spatial analysis, using geoprocessing tools or statistical models 7,12,13,14,15,16,17,18,19,20,21,22,23,24,25. By analyzing the city of Presidente Prudente spatially, we found that disease cases have a particular behavior. VL cases advance, even if the prevalence is kept low. The Center for Zoonoses Control is always chasing the disease. Serosurveys have been conducted in areas of reported humans or canine cases, which has not been efficient in controlling the disease. Even though a guideline with recommendations focused on vectors, hosts, and human cases is available, the actions seem to be disconnected. Similar situation may be found in other endemic medium cities of Brazil .

\section{Methods}

Our study area is in Brazil's Southeastern Region, on the west side of São Paulo State (Figure 1). Presidente Prudente (coordinates $22^{\circ} 07^{\prime} 33^{\prime \prime} \mathrm{S}$ and $51^{\circ} 23^{\prime} 20^{\prime \prime} \mathrm{W}$ ) is an administrative municipality, that is, it concentrates industries, education, commerce, and health services in the region. The city's population was estimated at 230,371 inhabitants in 2020, and the demographic density at 408.4 per $\mathrm{km}^{2} 26$. Two main highways traverse Presidente Prudente: the SP-270 and SP-425, giving access to the capital of the state (city of São Paulo) and Paraná State (at the Southern Brazil). There are 301 census tracts in the urban area of Presidente Prudente and seven surveillance areas used for municipal management and planning. 


\section{Figure 1}

Location of the city of Presidente Prudente, São Paulo State, Brazil.

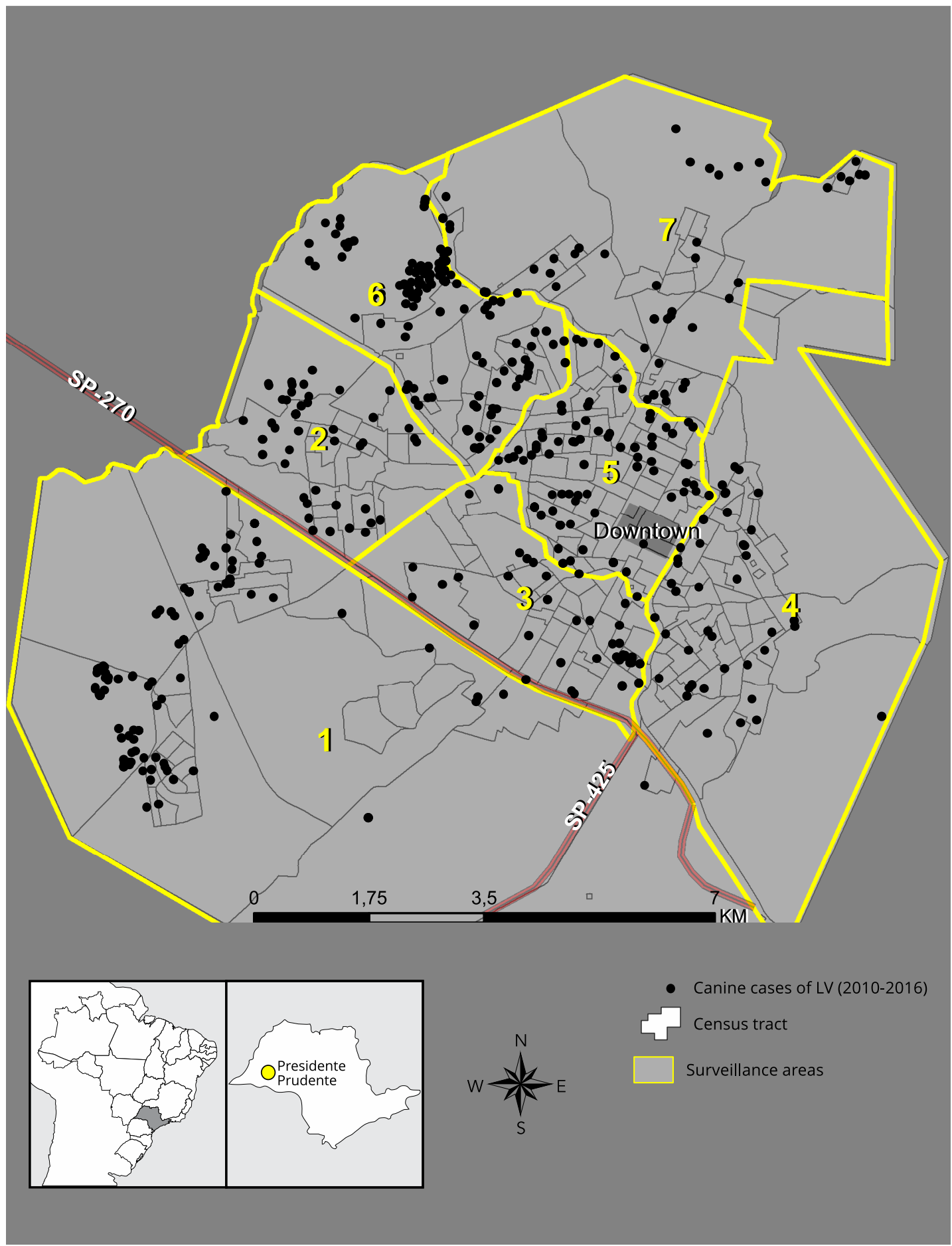




\section{Diagnosis data}

Data from Municipal Health Department of Presidente Prudente was used. Our period of study was from 2010 to 2016. Until 2012, diagnoses were tested by ELISA (Enzyme-Linked Immunosorbent Assay, BioManguinhos, Rio de Janeiro, Brazil) and confirmed by IFI (indirect fluorescent immunoassay, BioManguinhos, Rio de Janeiro, Brazil). Parasitological diagnoses were the minority. In 2012, a chromatographic immunoassay based on Dual Path Platform technology (DPP rapid test, BioManguinhos, Rio de Janeiro, Brazil) became the screening test and ELISA the confirmatory one 27 . According to both screening tests and confirmed diagnoses, our records consider all the diagnoses mentioned.

\section{Estimation of the canine population}

The canine population of Presidente Prudente was estimated based on the study of Alves et al. 28, considering the number of inhabitants and the São Paulo Index of Social Responsibility (IPRS 29) in the estimative. In this study, for the municipalities of the state of São Paulo, they calculated an average of 1:4 dogs/people ratio, approximately 0.25 dogs per person. Then, the canine population in Presidente Prudente weas estimated at 57,592 dogs 26 . The number of dogs was also estimated in each census tract using the 2010 census, as follows in Equation 1:

$$
\Delta \mathrm{d}=\Delta \mathrm{p} \times 0.25
$$

Where: $\Delta d$ is the estimation of the canine population; $\Delta p$ is the human population in the census tract. Then, Equation 1 was used to calculate the disease prevalence (Equation 2), defined as:

$$
f(\Delta \mathrm{c}, \Delta \mathrm{d}, \kappa)=\frac{\Delta \mathrm{c}}{\Delta \mathrm{d}} \times \kappa
$$

Where: $\kappa$ is an arbitrary constant; $\Delta c$ is the number of canine cases of VL.

\section{Geoprocessing and spatial analysis}

CVL data were available by address. The ArcGIS 10.2.2 (http://www.esri.com/software/arcgis/index. html) geocoding tool was used to generate the coordinates of latitude and longitude of each address. Then, points were created as shapefiles. Points were transformed into areas using the spatial join tool, which allowed mapping the prevalence of census tracts. The serosurvey data were also mapped by address and transformed into areas using the Geographic Information System.

A collection of Choropleth maps was created for spatial analysis, showing the prevalence of CVL throughout the seven years (2010-2016). Furthermore, a collection of trend maps was created to show the movement of the disease cases versus the percentage of screening coverage, a layer that shows the ratio of the number of examined dogs, and the dogs estimative in each census tract.

Finally, Local Moran's I (Equation 3) was used, providing measure for each census tract in the region, correlated with values in nearby areas:

$$
l_{i}=\mathrm{z}_{i} \sum_{j} w_{i j} z_{j}
$$

Where: $z_{i}$ and are standardized scores of attribute values for unit $i$ and $j ; l_{j}$ is among the identified neighbors of , conforming to the weights matrix $w_{i j}$.

We defined the conceptualization of contiguity edges corners for polygons and Euclidean distance as our mapping parameters, with 5\% significance level. The local spatial autocorrelation is based on LISA (Local Indicators of Spatial Autocorrelation). A measure of spatial association is estimated for each location, in which +1 indicates strong positive spatial autocorrelation, and -1 indicates strong negative spatial autocorrelation, and 0 (zero) indicates random spatial ordering 30 . Spatial autocorrelation defines a neighborhood around each geographic unit and explores the spatial dependence of deviation in attribute values from the second-order properties 31. 
In the Moran Scatter Plot, the four quadrants of a graph provide a classification of the spatial autocorrelation: high-high (upper right), low-low (lower left), for positive spatial autocorrelation. On the other hand, high-low (lower right) and low-high (upper left), for negative spatial autocorrelation. For LISA map interpretation, the hotspots theory was introduced, where a cluster is characterized by a census tract with positive autocorrelation with neighborhoods in the same situation (high-high or low-low relationship). When a census tract is positive, and other is negative, this is a high-low or a low-high relationship, entitled outliers. Hotspots neighbors that have at least one side touching the other present first-order contiguity between them 32 .

\section{Results}

Our study analyzed a seven-year window from 2010 to 2016. According to Table 1, a large number of dogs were evaluated, and most of the diagnoses were non-reagent. However, CVL cases increased progressively since the first reported case, with a peak in 2015.

Figure 2 presents a three-year moving average of CVL. From 2010-2012 to 2012-2014, CVL cases were stable, and then, there was an increase of $164 \%$ and $82 \%$ in the 2013-2015 and 2014-2016 triennium, respectively.

We observed a change in the disease spread pattern by analyzing the city's space (Figure 3 ). The first canine case was reported in 2010. From 2010 to 2014, CVL cases and prevalence were mostly in the central areas. In 2015, the spatial pattern of higher prevalence and number of cases changed to the outskirts. A growth in the Northwest (Area 6) can be noted, with neighboring areas with medium or high prevalence. In the Southeast, besides the higher prevalence, the number of cases (absolute variable - proportional circles) is smaller. In all seven-years (2010-2016), both higher prevalence and number of cases occurred in the city's outskirts.

Figure 4 represents the movement of the trend of CVL. From 2010 to 2011, the trend comes from the Northeast to the Southwest. In 2012, the higher trend moved to the extreme North (Areas 6 and 7) and, in 2014, to the Southeast (Area 4). Then, the Northwest Region, since 2014, have been presenting a higher trend. Overall, this is the direction of all the period (2010-2016).

Figure 4 shows the conducted serosurvey regarding the number of dogs per census tract. We observed a higher trend in Area 6 in 2011, when dogs were examined primarily in Areas 1,2, and 3. In

Table 1

Number of cases of canine visceral leishmaniasis and serosurvey conducted in the city of Presidente Prudente, São Paulo State, Brazil, 2010-2016.

\begin{tabular}{lcccc}
\hline Year & $\begin{array}{c}\text { Serosurvey (number } \\
\text { of samples tested) }\end{array}$ & $\begin{array}{c}\text { Positive canine cases * } \\
\text { Negative canine cases or } \\
\text { inconclusive/Not found }\end{array}$ & Prevalence (\%) \\
\hline 2010 & 7,167 & 14 & - & 0.19 \\
2011 & 4,263 & 46 & - & 1.07 \\
$2012 * *$ & 8,413 & 30 & 8,116 & 0.35 \\
2013 & 8,980 & 34 & 8,566 & 0.37 \\
2014 & 8,530 & 39 & 7,894 & 0.45 \\
2015 & 3,570 & 196 & 3,146 & 5.49 \\
2016 & 16,357 & 256 & 15,339 & 1.56 \\
Total *** & 57,280 & 615 & 43,061 & 1.07 \\
\hline
\end{tabular}

Source: Municipal Health Department of Presidente Prudente and Adolfo Lutz Institute.

* Screened and confirmed test, according to the Brazilian Ministry of Health's recommendations;

** The serosurvey time series were firstly organized in 2012;

*** The difference between positive or negative/inconclusive/not found and the number of samples refers to retested diagnoses. 
Figure 2

Three-year moving average of cases of canine visceral leishmaniasis (CVL), city of Presidente Prudente, São Paulo State, Brazil, $2010-2016$.

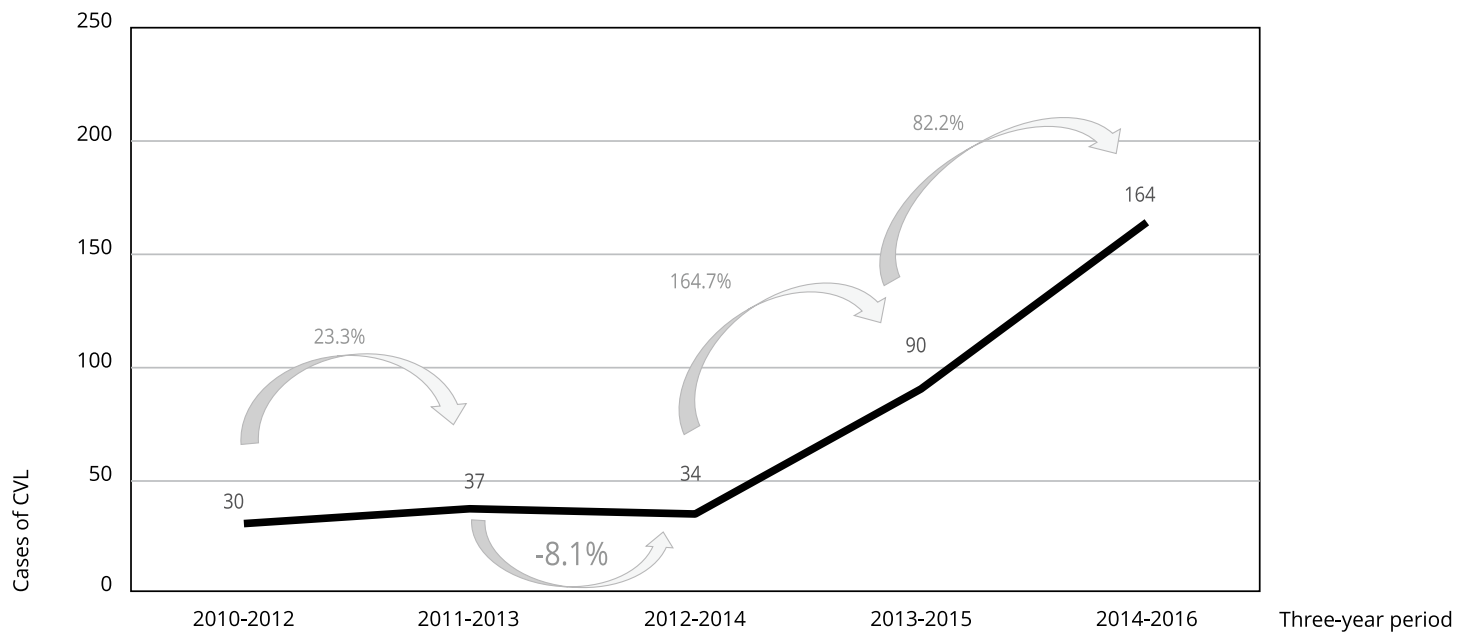

2012 the higher trend corresponded to higher coverage areas in Areas 5, 6, and 7. However, in 2013, low coverage $(<25 \%)$ was found in all areas, but the high tendency is in Area 4, where a higher coverage in the next year (2014) was observed between Areas 3 and 4.

We emphasize that since 2014, Area 6 presented a higher number of cases in all historical series, with the maximum value in this area in 2015, expanding to Area 7 (Figure 3). In 2016, Area 6 showed a decrease, but it was a significant area, considering the number of cases. Overall, the Northwest has a higher number of cases, prevalence (Figure 3), and the trend (Figure 4), historically a critical area regarding CVL. Moreover, most census tracts were covered in more than 50\% in all period (20102016), that is, seven years.

Finally, Moran's index (Figure 5; Table 2) demonstrates a positive and very weak spatial autocorrelation annually, with statistical significance for 2011, 2013, 2015, and 2016. From 2010 to 2016, the spatial autocorrelation is stronger and statistically significant $(I=0.2021$, p-value $<0,000)$. In 2011, we observed clustered areas of high-high relationship in the city's geographical center and the Northwest outskirt while outliers are nearby main streets and the SP-270. In 2013, nearby one of the high-low outliers, there are clustered areas in the Southeast. Finally, in 2015 and 2016, clustered areas changed to the Northwest of the city, with an outlier in the North area. The overall period has clustered census tracts in the Northwest of the city. The higher prevalence and trend from 2010 to 2016 (Figures 3 and 4) is broadly consistent with this cluster. 


\section{Figure 3}

Prevalence and cases of canine visceral leishmaniasis in the city of Presidente Prudente, São Paulo State, Brazil, $2010-2016$.

3a) 2010 *

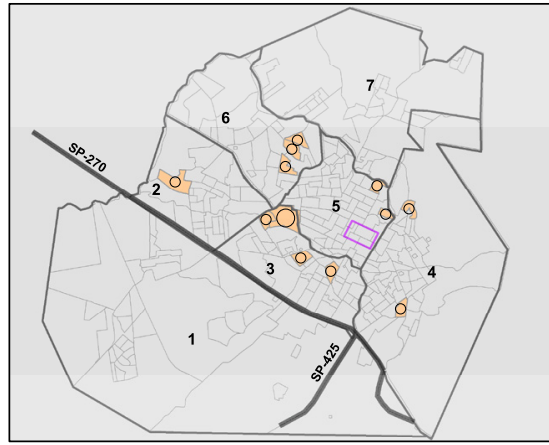

3d) 2013

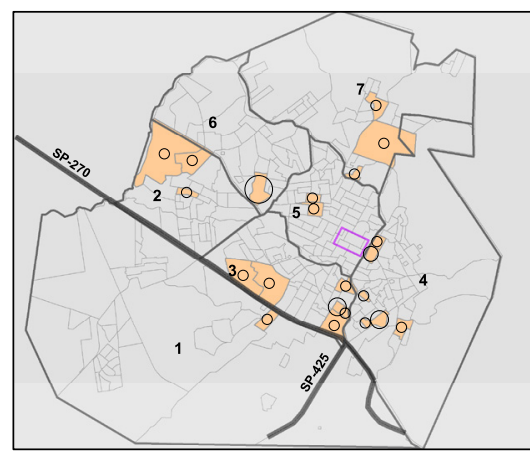

3g) 2016
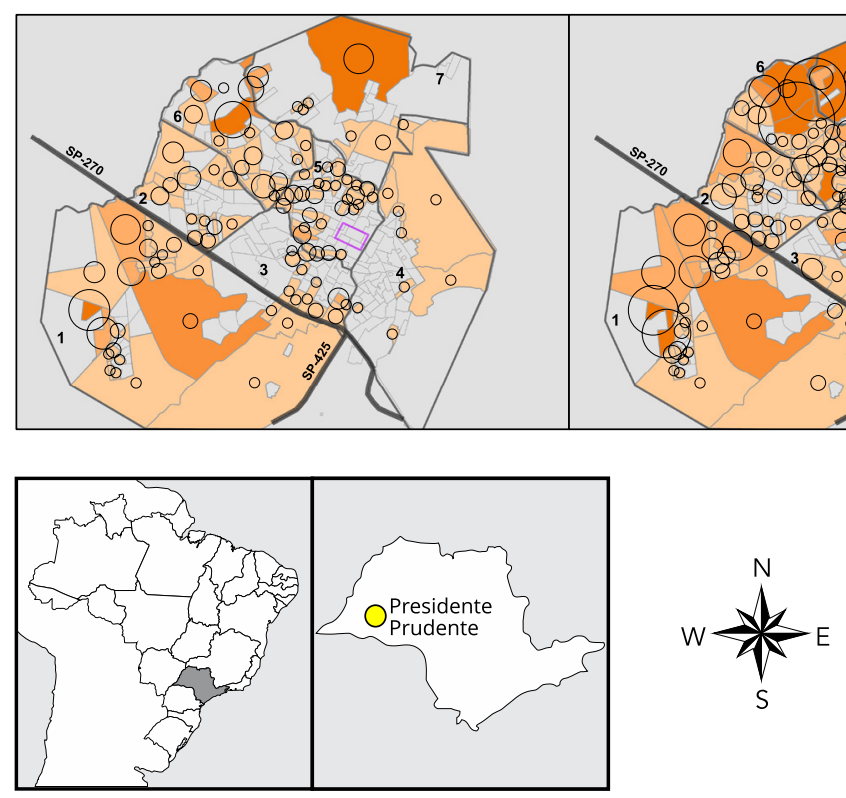

Total $2010-2016$

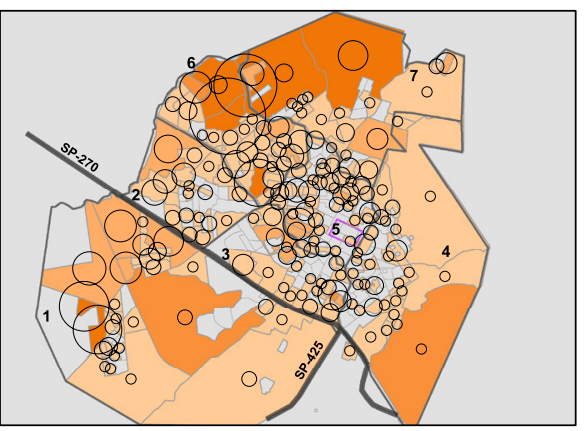

3b) 2011

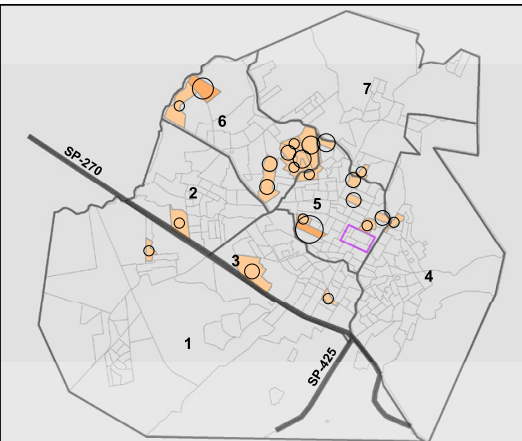

3e) 2014
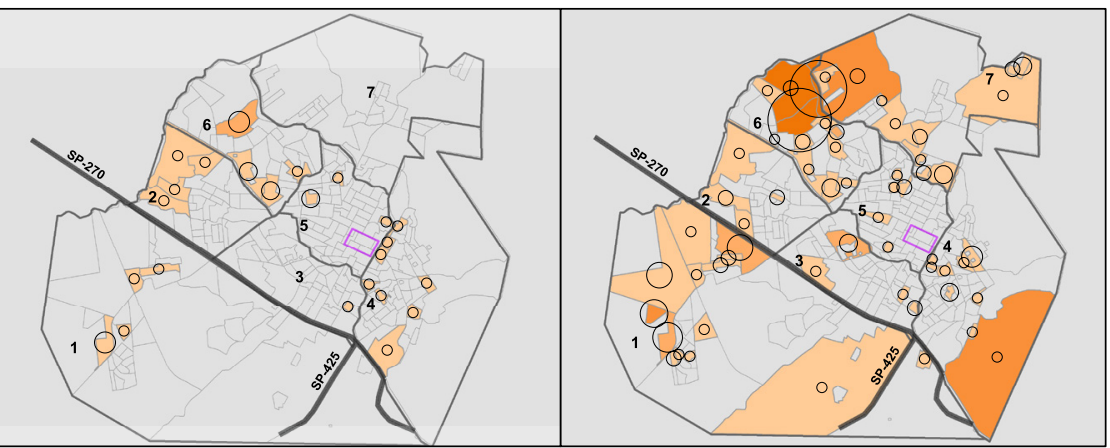

Canine visceral leishmaniasis (CVL)

Number of cases

Prevalence (\%)

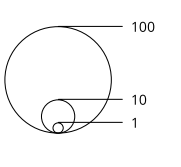

$\square 0.0$

$\square>0.0-2.5$

Downtown

$>2.5-5.0$

Surveillance areas

$>5.0-7.5$

$>7.5$

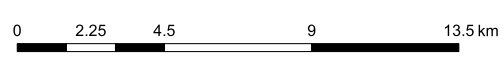

Datum: SIRGAS 2000. Coordinate System: UTM 22 S. Projection: Mercator.
Org.: 2021.

Source: Center for Zoonoses Control of Presidente Prudente and Adolfo Lutz Institute.

* 2010 and before. 


\section{Figure 4}

Trend of canine visceral leishmaniasis (CVL) and the canine serosurvey (conducted/estimated) in the city of Presidente Prudente, São Paulo State, Brazil, 2010-2016.

4a) 2010 *

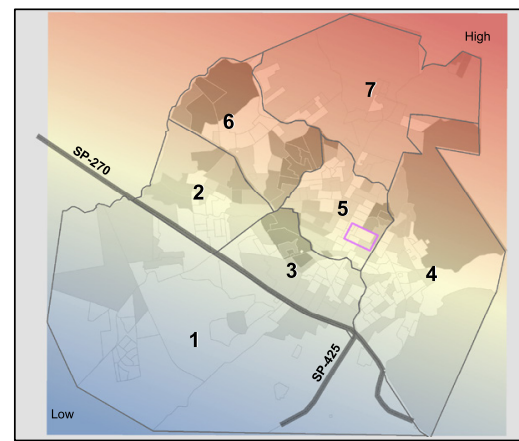

4d) 2013

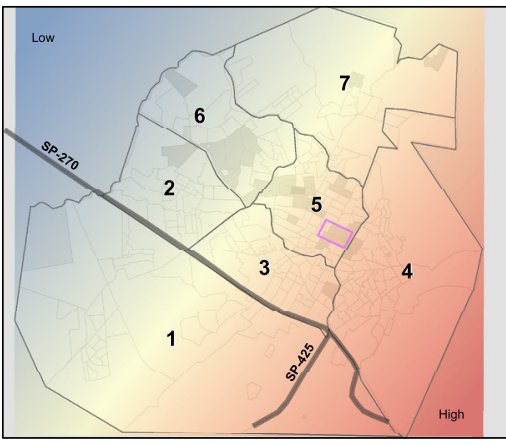

4e) 2014
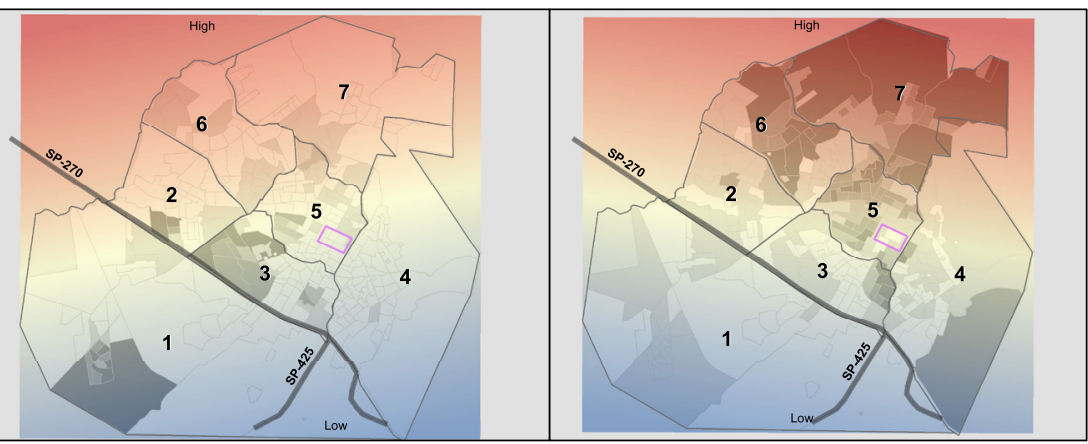

12014

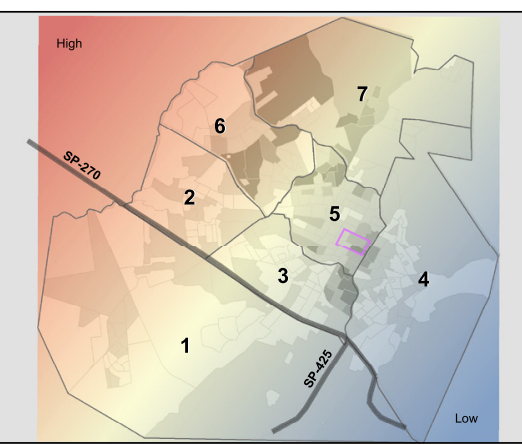

4f) 2015

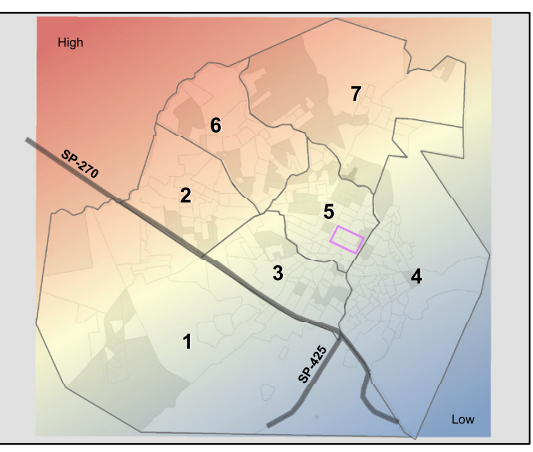

4g) 2016

4h) Total 2010-2016

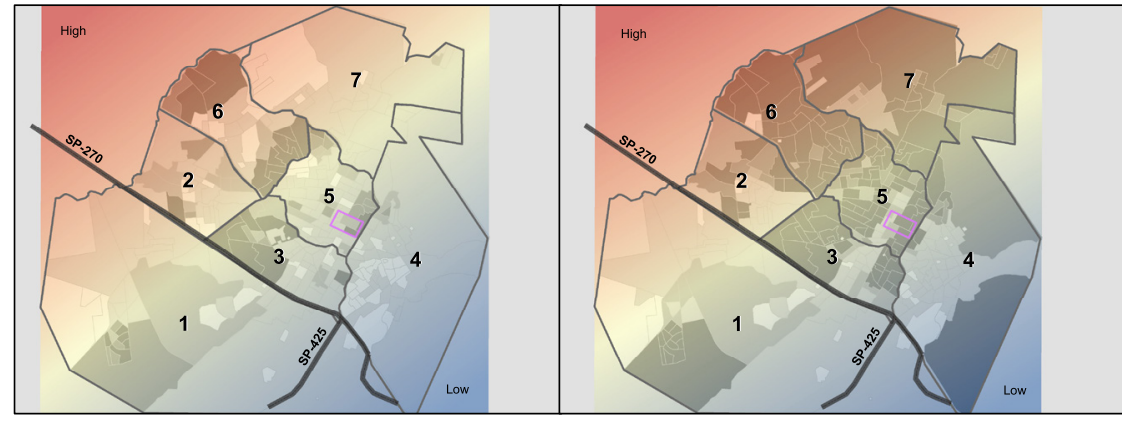

Trend of CVL

Canine serosurvey (\%)

Value

Conducted/Estimated

High
Medium
Low

$\square 0$

$\square>0-25$

$\square$ Downtown
$\square$ Surveillance areas

$>25-50$

$>75$
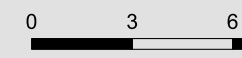

Datum: SIRGAS 2000. Coordinate System: UTM 22 S. Projection: Mercator. Org: 2021.
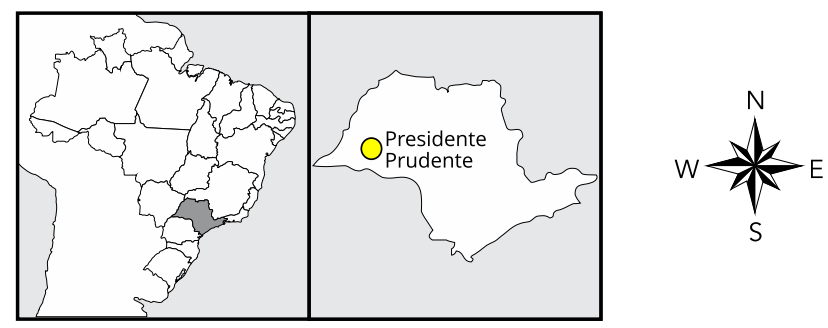

Source: Center for Zoonoses Control of Presidente Prudente.

* 2010 and before. 


\section{Figure 5}

Spatial autocorrelation for canine visceral leishmaniasis (CVL) in the city of Presidente Prudente, São Paulo State, Brazil, $2010-2016$.

5d) 2013 *

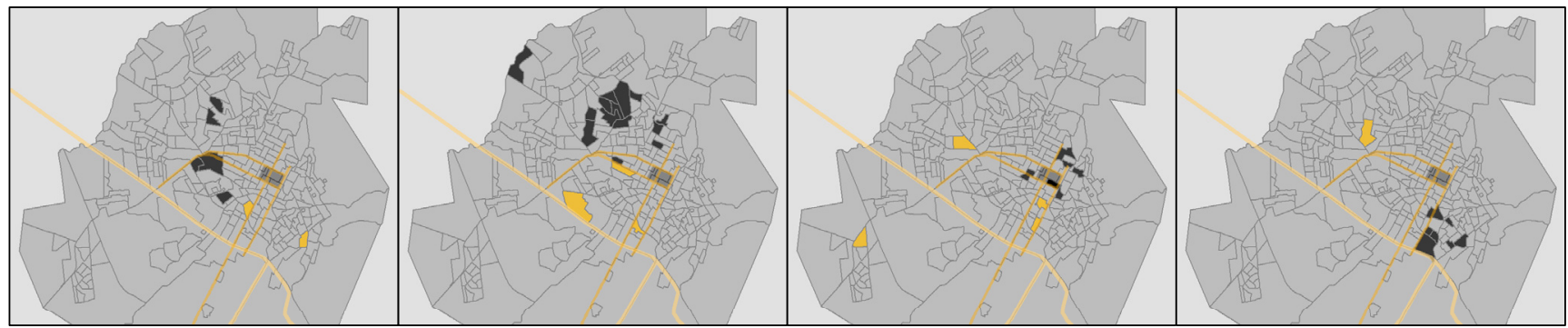

5e) 2014

5f) 2015 *

5g) 2016 *

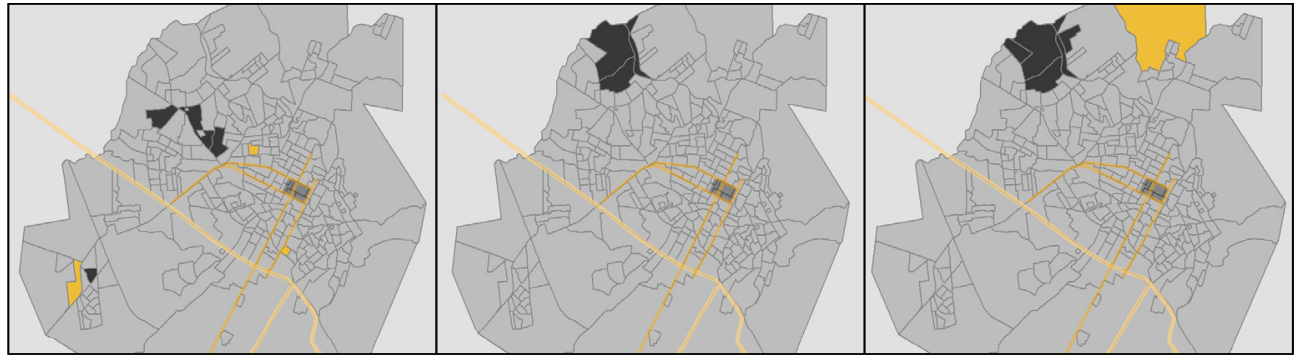

5h) $2010-2016$ *
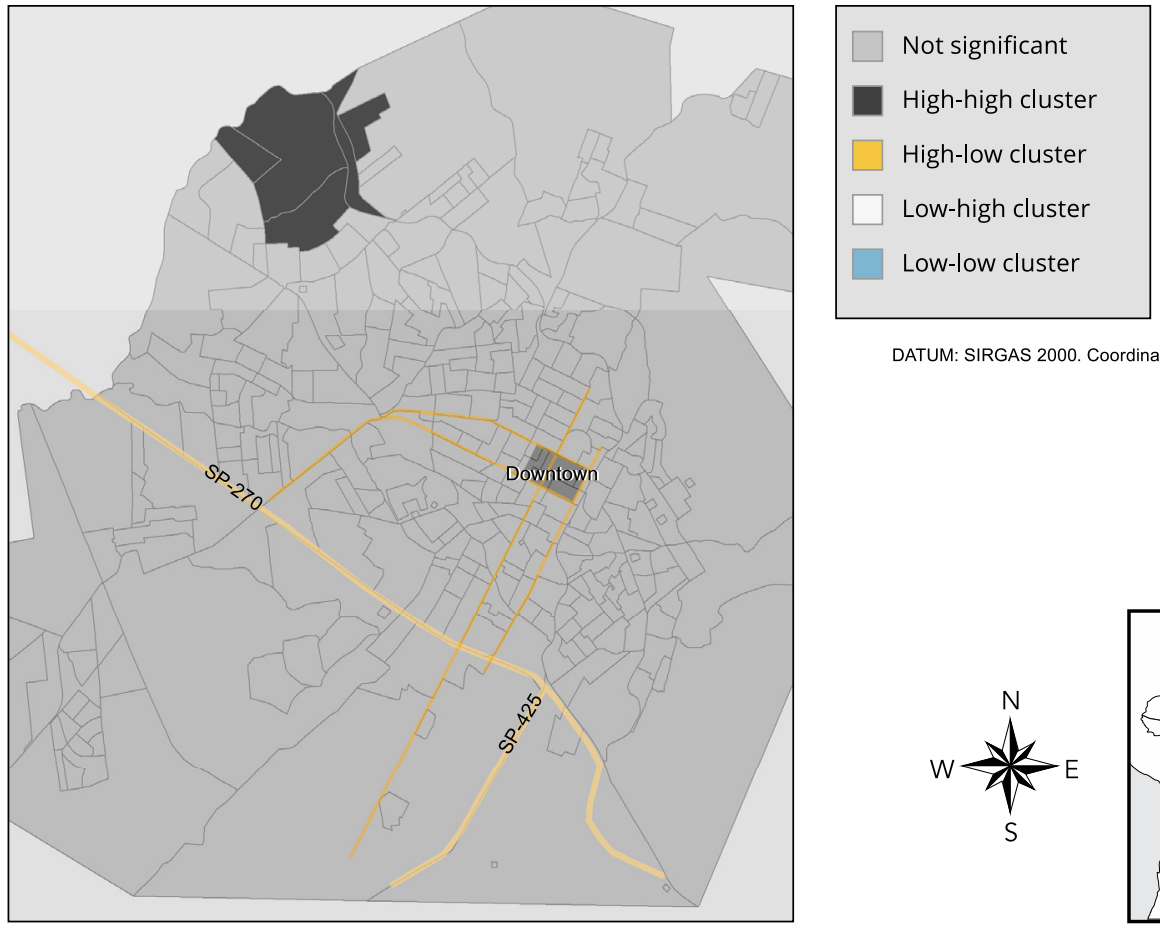

2010-2016

Global Moran's I Summary

Moran's Index: 0.202191

Expected Index: -0.003333

Variance: $\quad 0.000375$

z-score: $\quad 10.608754$

DATUM: SIRGAS 2000. Coordinate System: UTM 22 S. Projection: Mercator.
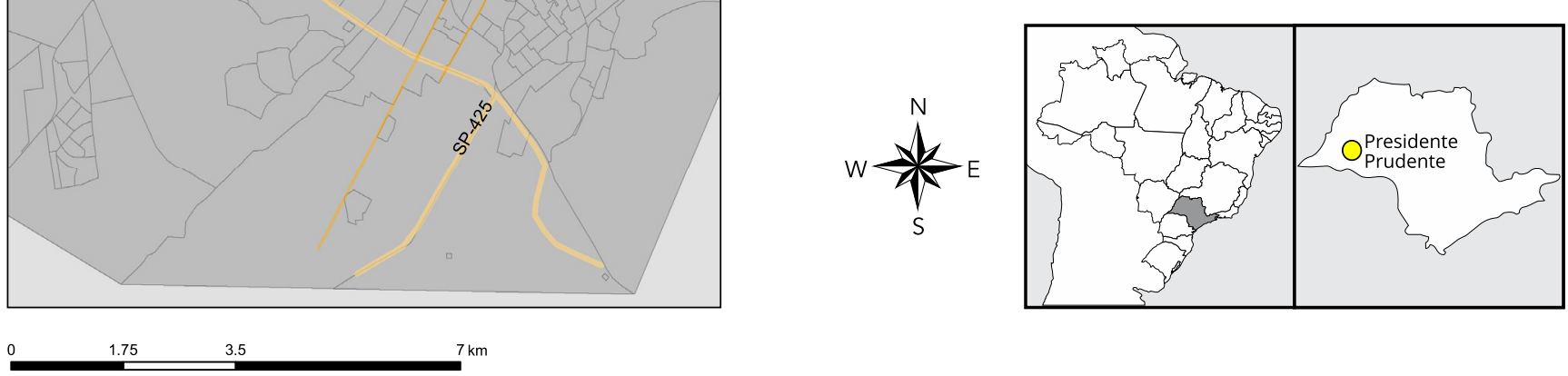

Source: Center for Zoonoses Control of Presidente Prudente.

* Statistical significance ( $p$-value $<0.05)$. 
Table 2

Spatial pattern of canine visceral leishmaniasis in the city of Presidente Prudente, São Paulo State, Brazil, $2010-2016$.

\begin{tabular}{llccc}
\hline Year & Pattern & Z-score & Moran's index & p-value \\
\hline 2010 & Random & 1.636198 & 0.041773 & 0.101798 \\
2011 & Clustered & 3.002109 & 0.089547 & 0.002681 * \\
2012 & Random & -0.110850 & -0.006933 & 0.911735 \\
2013 & Clustered & 2.072096 & 0.057103 & 0.038257 * \\
2014 & Random & -0.653906 & -0.020319 & 0.513172 \\
2015 & Clustered & 11.057344 & 0.204386 & 0.000000 * \\
2016 & Clustered & 5.345896 & 0.107989 & 0.000000 * \\
$2010-2016$ & Clustered & 10.608754 & 0.202191 & 0.000000 * \\
\hline
\end{tabular}

* Statistical significance, p-value $<0.05$.

\section{Discussion}

The discontinuity of control activities, resistance to euthanasia of dogs, and low coverage of chemicals against vectors are the main problems faced by local managers regarding VL 33 . We could add reduced budgets and the pressure of other diseases or health issues, such as dengue fever, the presence of scorpions, or other synanthropic animals. Brazilian Centers for Zoonoses Control work with a lack of human, equipment, and financial resources. Therefore, they do not monitor the canine population, neither conclude a serosurvey recovering all the canine population, nor even an annual sampling, planning the actions concerning the diagnoses prevision. Data on the population of dogs are hardly updated.

The canine population constantly changes in households, approximately 50\% in six months 34 . With this in mind, the human population seems to be an alternative to estimate the number of dogs once they are domestic animals. Literature has a variety of estimative proportions of dogs per inhabitant, ranging from $1: 2$ to $1: 535,36,37,38$. We used a ratio of $1: 428$, consistent with a medium-sized city of the state of São Paulo. We observed a low coverage of serological surveys in Brazilian cities 39,40, which have also been one of the most precise statistics for canines in Brazil. While canine monitoring is still insufficient, our methodology - estimating the number of dogs per census tract - offers a possibility to precisely investigate disease patterns. It can cover a lack of data in an area or lost temporal information.

In the city of Presidente Prudente, a massive difference in the number of examined dogs in 2014, 2015, and 2016 was detected. Besides, the shortage of DPP in 2015, affecting the municipalities of the state of São Paulo 41 was also observed. In this year, a high prevalence can be observed once the schedule for monitoring reservoirs was interrupted. Diagnostic tests were used in spontaneous demand, that is, dogs referred to the Center for Zoonoses Control with clinical symptoms and probably were positive, affecting prevalence rates. When CVL increased, the diagnostic kits were insufficient to perform planned canine serosurveys, emphasizing that monitor CVL in Brazilian cities is very difficult. Although the DPP shortage was normalized in 2016 - doubling the samples (Table 1) - the number of cases increased roughly $82 \%$, which stresses that only the serosurvey and culling dog may not be enough to control VL. The failure of both strategies may be due to the low coverage of the serosurveys 39 .

This study found that the spatial prevalence in the city of Presidente Prudente remained low until 2014 (<2.5\%). Nevertheless, dogs can be asymptomatic and a source of infection 42,43 , including asymptomatic seronegative individuals 44 , allowing VL to spread. In 2015, the prevalence had a spatial pattern of low values in the center and high values in the outskirts. Two reasons might have contributed to this pattern: the municipality borders have a higher number of dogs, and those are the boundaries between urban and rural areas. Vegetation creates a suitable habitat for vectors and may be related to infected dogs $25,45,46,47$. For the global prevalence (Table 1 ), we observed low rates $(<1.1 \%)$ from 2012 to 2014 and then a rapid increase in 2015 (5.4\%). The global prevalence was low 
(1\%) compared to another Brazilian state, e.g., 54\% in Mato Grosso 46, or even in an endemic city of São Paulo State with $8 \% 48$.

In urban areas, VL control is complex: (i) canine diagnoses are a challenge due to the operationalization of thousands of samples in the serosurveys 49; (ii) euthanasia is a social problem due to the relationship of the families with their dogs, increasingly adapted to humans; (iii) a long period of time between diagnosis and canine treatment or euthanasia may occur; (iv) there is a cultural habit of fast replacement of culled dogs or the introduction of new animals in the households 23,50,51, contributing to areas remaining endemic, and finally; (v) the Center for Zoonoses Control has planned its actions mainly focused on the location of human cases. However, it seeks to reach the disease. Considering Aristoteles' theory of Act (energeia, entelecheia) and Potency (dynamis) to Center for Zoonoses Control, we may rethink the path of VL between human or canine cases and their movement: who is and could turn out to be infected. The Center for Zoonoses Control needs to act faster, drawing up plans to prevent disease cases.

The higher trends and the location of the examined dogs follow different directions. The trends move in the city throughout the years. In many areas, no significant number of disease notifications occurred and then became visible. The movement starts with a single notification from any place in the city. Strategically, a couple of actions are performed in the area (or should be), such as serosurvey, environmental management, vectors control, and euthanasia, in accordance with Brazilian protocols 4. A break in the VL cycle is observed, but other epidemiological factors are still present. One clear example is the "bimodal pattern", that is, the decrease in canine positive results in a given year usually preceded by a higher positive rate in the previous year 39 . In other words, when control activities are executed, the number of cases decreases momentarily. Nonetheless, epidemiological aspects may not disappear due to favorable conditions to vector colonization, maintenance of infected dogs at households, or the replacement of euthanized ones. Additionally, neighboring households could have vectors and (asymptomatic) dogs.

The spatial trend (Figure 4) and the increasing number of cases (Figure 2) represent the Center for Zoonoses Control's reduced capacity in controlling CVL. We observed that, in 2015, when the maximum number of cases was registered in the Northwest Region (Figure 3, area 6), only a few samples were examined (Table 1; Figure 4). An increase in testing capacity was detected only in 2016, demonstrating a delay in case appearance and serosurvey. Additionally, the Northwest area, indicated with a high prevalence in 2015, had a lower prevalence in 2016, but neighboring areas still had medium prevalence, emphasizing that the Center for Zoonoses Control is trying to control disease cases, but not sufficiently. The spatial pattern of the difference in the trend and higher screening coverage is due to, most likely, the inquiries focused on human cases areas. The annual screening coverage never surpassed more than $50 \%$ in at least half of the municipality. These results corroborate the findings of a yearly screening coverage of below 50\% from 2012 to 2017 in another endemic Brazilian city 39. Conversely, the serosurvey conducted in all the historical period (2010-2016) demonstrated a high coverage $(>75 \%)$ in most areas of the city $(57,000$ pieces of data), which corresponds to the estimated canine population $(57,592)$. However, this was concluded in seven years, too long for the rapid response that the Center for Zoonoses Control and public health urge. This scenario is not only faced by the city of Presidente Prudente but by the Brazilian cities that have been trying to control VL for decades unsuccessfully.

VL surveillance and control actions must be taken as a priority by different public management levels. The measures are recommended by the National PCLV but executed by the local governments, which suffer the pressure of the dog's guardians and animal protection organizations, affecting the local elections and politicians' popularity. Even in the scientific community, euthanasia has been deeply discussed 41,51,52,53,54. The debate concerning the possibility of introduction of new control strategies regarding CVL - treatment, vaccines, selected euthanasia of symptomatic dogs, and the use of insecticides 52,53 - based on scientific evidence that considers the participation of the society in a horizontal construction of a health system increasingly participatory, plural, and effective 49. Therefore, socioeconomic, cultural, political, and environmental conditions play an essential role in the directions that cases may be following in a city.

The positive spatial autocorrelation of CVL per year highlights the relationship that the value at a location and its neighbor regions are influence by each other. In 2011, the spatial pattern 
showed the existence of clusters of high-high relationships and outliers in different areas of the city (Figure 5). Then, the areas near the high-low outliers have clustered areas of high-high relationship in 2013 (Figure 5). Outliers are clues to investigate which areas can turn into clustered areas. Overall, from 2010 to 2016 , the spatial autocorrelation was positive $(I=0.2$, p-value $<0.000)$ and statistically significant (Figure 5), allowing us to better comprehend the spatial disease pattern. We indicated one big cluster of high-high relationships in the Northwest, broadly consistent with the trend. The lower prevalence is consistent with polygons of no statistical significance and spatial autocorrelation. Our results corroborate the finds in Argentina in 2014, where the higher prevalence areas are overlapped in the high-high cluster or high-low outliers 55 .

Furthermore, it has been suggested that the human VL clusters can emerge after the CVL clusters, with a temporal association between the two outcomes 56 . The high-high clusters and the high-low outliers are priority areas to intervene and to monitor. Then, the Centers for Zoonoses Control can arrive first, with preventive measures. The non-significant polygons describe random risk areas, that is, all areas will be at risk and represent a lower priority for intervention than the area presented as a high-high cluster. Our recommendation is to monitor all areas, but mainly those highlighted as a priority.

Geography knowledge, with spatial analysis, can provide clues of priority areas thinking of an integrated approach. Spatial analysis is a way to minimize the distance between the path of Centers for Zoonoses Control and disease spread. This informations could help predict where VL will be and what pattern it will take. Spatial analysis studies help us to understand the behavior of the disease and its background. Nevertheless, the Centers for Zoonoses Control seem to be far from absorbing these technologies. These tools need to be used by public policies to plan VL control once the disease is an issue of particular concern to local health authorities. We emphasize that the Centers for Zoonoses Control represent one of the practices of public health. The success of control measures will depend on integrated actions from three public health practices against VL: the vectors control, epidemiologic surveillance, and Center for Zoonoses Control, using geographical knowledge to support decision-making.

Finally, this study had limitations that should be acknowledged. The canine estimation assumed that all percentage of dogs calculated by a city, in this case Presidente Prudente, is parallel to the human population. We recognize that neighborhoods can be different and that the proportion of dogs per inhabitant could change inside the city. Yet, when no recorded database of dogs is available, the estimation can help calculate the local prevalence. We used different data in our analysis, such as the real number of examined dogs and the estimative, aware of the need to change data when necessary.

\section{Conclusion}

We applied statistical techniques and generated thematic cartography maps. Our methodology allowed analyzing canine visceral leishmaniasis in the space, identifying priority intervention areas. As the patterns are constantly changing, the Center for Zoonoses Control needs to be prepared to face VL. We emphasize using spatial analysis to support decision-making, drawing up strategies to make health services react faster than disease spreading. 


\section{Contributors}

P. S. S. Matsumoto contributed to the conceptualization of the study, methodology, data curation, formal analysis, writing, reviewing and editing the text. E. F. Flores contributed to the methodology, formal analysis, writing, review and editing the text. J. S. Barbosa contributed to the methodology, writing, reviewing and editing the text. U. C. Pessoto and J. E. Tolezano contributed to the writing, revision and editing of the text. R. M. Hiramoto and H. H. Taniguchi contributed to the data curation, writing, revision and editing the text. R. B. Guimarães contributed to the conceptualization of the study, writing, reviewing and editing the text. All authors have approved the final version for publication.

\section{Additional informations}

ORCID: Patricia Sayuri Silvestre Matsumoto (0000-0001-7205-7557); Edilson Ferreira Flores (0000-0001-7385-6705); José Seguinot Barbosa (0000-0003-1480-3552); Umberto Catarino Pessoto (0000-0001-6682-107X); José Eduardo Tolezano (0000-0003-3055-0508); Roberto Mitsuyoshi Hiramoto (0000-0002-7404-1505); Helena Hilomi Taniguchi (0000-0002-3998-6896); Raul Borges Guimarães (0000-0002-9925-5374).

\section{Acknowledgments}

We would like to thank the Center for Zoonoses Control of Presidente Prudente for the data and the São Paulo State Research Foundation (FAPESP) for funding our study (grant n. 2014/27070-1, 2019/22246-8).

\section{Conflict of interests}

The authors declare no conflict of interest.

\section{References}

1. Pan American Health Organization. Leishmaniases: epidemiological report of the Americas. (Leishmaniasis Report 7). https://iris. paho.org/bitstream/handle/10665.2/50505/ Leishreport2019_eng.pdf (accessed on 16/ Dec/2019).

2. Conceição-Silva F, Alves CR. Leishmanioses do continente americano. Rio de Janeiro: Editora Fiocruz; 2014.

3. Rangel EF, Lainson R. Flebotomíneos do Brasil. Rio de Janeiro: Editora Fiocruz; 2003.

4. Departamento de Vigilância Epidemiológica, Secretaria de Vigilância em Saúde, Ministério da Saúde. Manual de vigilância e controle da leishmaniose visceral. http://bvsms.saude.gov. br/bvs/publicacoes/manual_vigilancia_con trole_leishmaniose_visceral_1edicao.pdf (accessed on 21/Sep/2018).

5. Pan American Health Organization. Leishmaniasis: epidemiological report in the Americas. (Leishmaniasis Report 8). https://iris. paho.org/handle/10665.2/51734 (accessed on 11/Sep/2020)

6. Ministério da Saúde. Casos confirmados de leishmaniose visceral, Brasil, Grandes Regiões e Unidades Federadas. 1990 a 2013. https://portalarquivos2.saude.gov.br/images/ pdf/2014/setembro/09/LV-Casos.pdf (accessed on 11/Sep/2020).

7. Camargo-Neves VLF, Katz G, Rodas LAC, Poletto DW, Lage LC, Spínola RMF, et al. Utilização de ferramentas de análise espacial na vigilância epidemiológica de leishmaniose visceral americana - Araçatuba, São Paulo, Brasil, 19981999. Cad Saúde Pública 2001; 17:1263-7.

8. Matsumoto PSS. Análise espacial da leishmaniose visceral canina em Presidente Prudente - SP - Brasil [Master Thesis]. Presidente Prudente: Universidade Estadual Paulista; 2014.

9. Centro de Vigilância Epidemiológica. Casos e óbitos de leishmaniose visceral segundo município de infecção e ano de notificação, Estado de São Paulo, 1999 a 2016. http://cve.saude. sp.gov.br/resources/cve-centro-de-vigilan cia-epidemiologica/areas-de-vigilancia/doen cas-de-transmissao-por-vetores-e-zoonoses/ dados/leish/lv9916_sh_gve.htm (accessed on 10/Sep/2020).

10. Ministério da Agricultura, Pecuária e Abastecimento. Nota técnica no 001/2016 MAPA/MS. Processo no 21000.042544/2016-94. http:// www.sbmt.org.br/portal/wp-content/ uploads/2016/09/nota-tecnica.pdf (accessed on 21/Aug/2020).

11. Prefeitura de Presidente Prudente. Lei no 9.250, de 2016. Dispõe sobre o tratamento da leishmaniose visceral canina (LVC) no âmbito do Município de Presidente Prudente e dá outras providências. http://www.presidentepru dente.sp.gov.br/site/documento/35228 (accessed on 12/May/2020). 
12. Lara-Silva FO, Michalsky EM, Fortes-Dias CL, Fiuza VOPF, Pessanha JEM, Regina-Silva S, et al. Epidemiological aspects of vector, parasite, and domestic reservoir in areas of recent transmission and no reported human cases of visceral leishmaniasis in Brazil. Acta Trop 2015; 148:128-36.

13. Almeida AS, Werneck GL. Prediction of highrisk areas for visceral leishmaniasis using socioeconomic indicators and remote sensing data. Int J Health Geogr 2014; 13:13.

14. Teixeira-Neto R, Silva ES, Nascimento RA, Belo VS, Oliveira CL, Pinheiro LC, et al. Canine visceral leishmaniasis in an urban setting of Southeastern Brazil: an ecological study involving spatial analysis. Parasit Vectors 2014; $7: 485$.

15. Margonari C, Freitas CZ, Ribeiro RC, Moura ACM, Timbó M, Gripp AH, et al. Epidemiology of visceral leishmaniasis through spatial analysis, in Belo Horizonte municipality, state of Minas Gerais, Brazil. Mem Inst Oswaldo Cruz 2006; 101:31-8.

16. Enternece GL, Costa CHA, Walter AM, David JR, Andana M, Maguiraze JH. The urban spread of visceral leishmaniasis: clues from spatial analysis. Epidemiology 2002; 13:364-7.

17. Casanova C, Colla-Jacques FE, Hamilton JGC, Brazil RP, Shaw JJ. Distribution of Lutzomyia longipalpis chemotype populations in São Paulo state, Brazil. PLoS Negl Trop Dis 2015; 9:e0003620.

18. Araujo VEM, Pinheiro LC, Almeida MCM, Menezes FC, Morais MHF, Reis IA, et al. Relative risk of visceral leishmaniasis in Brazil: a spatial analysis in urban area. PLoS Negl Trop Dis 2013; $7: \mathrm{e} 2540$.

19. Chamaillé L, Tran A, Meunier A, Bourdoiseau G, Ready P, Dedet J. Environmental risk mapping of canine leishmaniasis in France. Parasit Vectors 2010; 3:31.

20. Cardim MFM, Vieira CP, Chiaravalloti-Neto, F. Spatial and spatiotemporal occurrence of human visceral leishmaniasis in Adamantina, State of São Paulo, Brazil. Rev Soc Bras Med Trop 2015; 48:716-23.

21. Salomón OD, Orellano PW, Lamfri M, Scavuzzo M, Dri L, Farace MI, et al. Phlebotominae spatial distribution asssociated with a focus of tegumentary leishmaniasis in Las Lomitas, Formosa, Argentina, 2002. Mem Inst Oswaldo Cruz 2006; 101:295-9.

22. Hartemink N, Vanwambeke SO, Heesterbeek H, Rogers D, Morley D, Pesson B, et al. Integrated mapping of establishment risk for emerging vector-borne infections: a case study of canine leishmaniasis in southwest France. PLoS One 2011; 6:e20817.

23. Vieira CP, Oliveira AM, Rodas LAC, Dibo MR, Guirado MM, Chiaravalloti-Neto F. Temporal, spatial and spatiotemporal analysis of the occurrence of visceral leishmaniasis in humans in the city of Birigui, State of São Paulo, from 1999 to 2012. Rev Soc Bras Med Trop 2014; 47:350-8.
24. Gomes-Barroso D, Herrador Z, Martín JVS, Gherasim A, Aguado M. Spatial distribution and cluster analysis of a leishmaniasis outbreak in the south-western Madrid region, Spain, September 2009 to April 2013. Euro Surveill 2015; 20:11-20.

25. Menezes JA, Ferreira EC, Andrade-Filho JD, Sousa AM, Morais MHG, Rocha AMS, et al. An integrated approach using spatial analysis to study the risk factors for leishmaniasis in area of recent transmission. Biomed Res Int 2015; 2015:621854.

26. Instituto Brasileiro de Geografia e Estatística. Cidades@. Presidente Prudente. https://cida des.ibge.gov.br/brasil/sp/presidente-pruden te/panorama (accessed on 07/Sep/2020).

27. Departamento de Vigilância das Doenças Transmissíveis, Secretaria de Vigilância em Saúde, Ministério da Saúde. Nota Técnica Conjunta n. 1/2011. http://www.sgc.goias.gov. br/upload/arquivos/2012-05/nota-tecnicano.-1-2011_cglab_cgdt1_lvc.pdf (accessed on 15/Jul/2020).

28. Alves MCGP, Matos MR, Reichmann MDL, Dominguez MH. Estimation of the dog and cat population in the State of São Paulo. Rev Saúde Pública 2005; 39:891-7.

29. Fundação Sistema Estadual de Análise de Dados. Índice Paulista de Responsabilidade Social (IPRS). https://iprs.seade.gov.br/ (accessed on 12/Dec/2020).

30. Anselin L. Exploring spatial data with GeoDa TM: a workbook. Santa Barbara: Center for Spatially Integrated Social Science; 2005.

31. Bailey TC, Gatrell AC. Interactive spatial data analysis. Harlow: Longman; 1995.

32. Ferreira MC. Iniciação à análise geoespacial: teoria, técnicas e exemplos para geoprocessamento. São Paulo: Editora Unesp; 2014.

33. von Zuben APB, Donalísio MR. Dificuldades na execução das diretrizes do Programa de Vigilância e Controle da Leishmaniose Visceral em grandes municípios brasileiros. Cad Saúde Pública 2016; 32:e00087415.

34. Tolezano JE, Matsumoto PSS, Taniguchi $\mathrm{HH}$ Bertollo DMB, Pierre MK, Raeffray JE, et al. Avaliação da efetividade do uso de coleiras impregnadas com deltametrina no controle da leishmaniose visceral no município de Votuporanga, Estado de São Paulo, Brasil, 20142016. Rev Inst Adolfo Lutz 2018; 77:e1764.

35. Catapan DC, Villanova-Junior JA, Weber SH, Mangrich RMV, Szczypkovski AD, Capatan A, et al. Estimativa populacional e programa de esterilização cirúrgica de cães e gatos. Acta Vet Brasilica 2015; 9:259-73.

36. Baquero OS, Marconcin S, Rocha A, Garcia RCM. Companion animal demography and population management in Pinhais, Brazil. Prev Vet Med 2018; 158:169-77.

37. Andrade AM, Queiroz LH, Perri SH, Nunes CM. Estudo descritivo da estrutura populacional canina da área urbana de Araçatuba, São Paulo, Brasil, no período de 1994 a 2004. Cad Saúde Pública 2008; 24:927-32. 
38. Dias RA, Garcia RC, Silva DF, Amaku M, Ferreira-Neto JS, Ferreira F. Estimativa de populações canina e felina domiciliadas em zona urbana do Estado de São Paulo. Rev Saúde Pública 2004; 38:565-70.

39. Sousa-Paula LC, Silva LG, Sales KGS, DantasTorres F. Failure of the dog culling strategy in controlling human visceral leishmaniasis in Brazil: a screening coverage issue? PLoS Negl Trop Dis 2019; 13:e0007553.

40. Costa DNCC, Bermudi PMM, Rodas LAC, Nunes CM, Hiramoto RM, Tolezano JE, et al. Human visceral leishmaniasis and relationship with vector and canine control measures. Rev Saúde Pública 2018; 52:92.

41. Henshel PFF. Leishmaniose visceral no estado de São Paulo, Brasil: avaliação das ações de vigilância e controle no centro-oeste paulista, de 1999 a 2018, região endêmica para lleishmaniose tegumentar [Doctoral Dissertation]. São Paulo: Secretaria Estadual de Saúde de São Paulo; 2019.

42. Laurenti MD, Rossi CN, Matta VLR, Tomokane TY, Corbett CEP, Secundino NFC, et al. Asymptomatic dogs are highly competent to transmit Leishmania (Leishmania) infantum chagasi to the natural vector. Vet Parasitol 2013; 196:296-300.

43. Donato LE, Lima Júnior FEF, Alburquerque R, Gomes MLS. Vigilância e controle de reservatórios da leishmaniose visceral no Brasil: aspectos técnicos e jurídicos. Revista de Educação Continuada em Medicina Veterinária e Zootecnia do CRMV-SP 2013; 11:18-23.

44. Lopes EG, Sevá AP, Ferreira F, Nunes CM, Keide LB, Hiramoto RM, et al. Serological and molecular diagnostic tests for canine visceral leishmaniasis in Brazilian endemic area: one out of five seronegative dogs are infected. Epidemiol Infect 2017; 145:2436-44.

45. Figueiredo ABF, Werneck GL, Cruz MSP, Silva JP, Almeida AS. Land use, land cover, and prevalence of canine visceral leishmaniasis in Teresina, Piauí State, Brazil: an approach using orbital remote sensing. Cad Saúde Pública 2017; 33:e00093516.

46. Lopes PM, Sorte ECB, Gasparetto ND, Oliveira CM, Almeida ABPF, Sousa VRF. Seroprevalence and risk factors associated with visceral leishmaniasis in dogs in Jaciara, state of Mato Grosso. Rev Soc Bras Med Trop 2014; 47:791-5.

47. Costa AP, Costa FB, Soares HS, Ramirez DG, Araújo AC, Ferreira JIGS, et al. Environmental factors and ecosystems associated with canine visceral leishmaniasis in Northeastern Brazil. Vector Borne Zoonotic Dis 2015; 15:765-74.
48. Costa DNCC, Blangiardo M, Rodas LAC, Nunes CM, Hiramoto RM, Tolezano JE, et al. Canine visceral leishmaniasis in Araçatuba, State of São Paulo, Brazil, and its relationship with characteristics of dogs and their owners: a cross-sectional and spatial analysis using a geostatistical approach. BMC Vet Res 2018; 14:229.

49. Romero GAS. O controle de leishmaniose visceral no Brasil: transformar é preciso. Cad Saúde Pública 2016; 32:eCO010616.

50. Andrade AM, Queiroz LH, Nunes GR, Perri SHV, Nunes CM. Reposição de cães em área endêmica para leishmaniose visceral. Rev Soc Bras Med Trop 2007; 40:594-5.

51. Wilke VML. Avaliação das atividades de controle da leishmaniose visceral canina no município de Sabará, Minas Gerais, 1995 a 2000 [Masters Thesis]. Belo Horizonte: Universidade Federal de Minas Gerais; 2005.

52. Dantas-Torres F, Miró G, Bowman DD, Gradoni L, Otranto D. Culling dogs for zoonotic visceral leishmaniasis control: the wind of change. Trends Parasitol 2019; 35:97-101.

53. Dantas-Torres F, Miró G, Baneth G, Bourdeau P, Breitschwerdt E, Capelli G, et al. Canine leishmaniasis control in the context of one health. Emerg Infect Dis 2019; 25:1-4.

54. Machado CJS, Silva EG, Vilani RM. O uso de um instrumento de política de saúde pública controverso: a eutanásia de cães contaminados por leishmaniose no Brasil. Saúde Soc 2016; 25:247-58

55. Lamattina D, Berrozpe PE, Casas N, Moya SL, Giuliani MG, Costa CA, et al. Twice upon a time: the progression of canine visceral leishmaniasis in an Argentinean city. PLoS One 2019; 14:e0219395.

56. Arruda RMF, Cardoso DT, Teixeira-Neto RG, Barbosa DS, Ferraz RK, Morais MHF, et al. Space-time analysis of the incidence of human visceral leishmaniasis (VL) and prevalence of canine VL in a municipality of southeastern Brazil: identification of priority areas for surveillance and control. Acta Trop 2019: 197:105052. 


\section{Resumo}

A leishmaniose visceral ( $L V)$ é um problema de saúde pública nas cidades brasileiras. Por mais que haja um planejamento de políticas públicas para LV no Estado de São Paulo, Brasil, novos casos têm sido notificados e se disseminado. $O$ artigo objetiva discutir como o Centro de Controle de Zoonoses realiza suas atividades espacialmente em uma cidade endêmica, Presidente Prudente, no Estado de São Paulo. Os dados são da Secretaria Municipal de Saúde de Presidente Prudente, Instituto Adolfo Lutz e Instituto Brasileiro de Geografia e Estatística. Estimamos espacialmente a população canina por setor censitário e utilizamos ferramentas de geoprocessamento para produzir mapas coropléticos, tendências espaciais e autocorrelação espacial. Encontramos um padrão espacial de maior prevalência na periferia da cidade e uma autocorrelação espacial positiva estatisticamente significativa $(I=$ $0,2 ; p<0,000)$ com clusters de relação alta-alta no noroeste da cidade. Além disso, identificamos uma direção diferente no caminho dos inquéritos sorológicos realizados versus a tendência na $L V$ canina, o que enfatiza a fragilidade das medidas de controle do Centro de Controle de Zoonoses para controlar casos da doença. O Centro de Controle de Zoonoses parece estar sempre correndo atrás da doença. A análise espacial pode ser útil para repensar o funcionamento do serviço e auxiliar as políticas públicas.

Leishmaniose Visceral; Tomada de Decisões; Vigilância Epidemiológica

\section{Resumen}

La leishmaniasis visceral (LV) es un problema de salud pública en las ciudades brasileñas. Aunque hay políticas públicas de planificación relacionadas con la LV en el estado de São Paulo, Brasil, se han informado de nuevos casos, además de su propagación. El objetivo de este trabajo es discutir cómo el Centro de Control de Zoonosis dirige sus acciones espacialmente en una ciudad endémica del estado de São Paulo, Presidente Prudente. Los datos proceden de la Secretaría Municipal de Salud de Presidente Prudente, del Instituto Adolfo Lutz, y del Instituto Brasileño de Geografía y Estadística. Estimamos espacialmente la población de perros por sector censal y utilizamos herramientas de geoprocesamiento para elaborar mapas de coropletas, tendencias espaciales, $y$ autocorrelación espacial. Encontramos un patrón espacial de más alta prevalencia en la periferia de la ciudad, además de una autocorrelación espacial positiva y estadísticamente significativa $(I=0,2$; valor de $p$ $<0,000)$ con clústeres de relaciones alto-alto en la parte noroccidental de la ciudad. Además, identificamos una dirección diferente en la trayectoria de las encuestas serológicas llevadas a cabo, frente a la tendencia de LV canina, que enfatiza la debilidad de acciones del Centro de Control de Zoonosis para controlar casos de la enfermedad. El Centro de Control de Zoonosis parece siempre estar tras la enfermedad. El análisis espacial podría ser útil para repensar cómo está funcionando el servicio, además de ayudar a políticas públicas.

Leishmaniasis Visceral; Toma de Decisiones; Vigilancia Epidemiológica
Submitted on $18 /$ Sep/ 2020

Final version resubmitted on 25/Mar/2021

Approved on 12/Apr/2021 